\title{
BOTANICAL INVESTIGATIONS ON Asparagus officinalis L. plant (ASPARAGACEAE)
}

\author{
(Received:20.2.2015)
}

\author{
By \\ R.K. Harb , O.S. El- Kobisy and S. F. Desoukey \\ Department.of Agriculture Botany, Faculty of Agriculture, Cairo University, Giza, Egypt.
}

\begin{abstract}
The present study deals with the botanical investigations as well as Scanning Electron Microscope (SEM) on Asparagus officinalis L. plant (Asparagaceae). Asparagus is a herbaceous, perennial plant that grows up to $1-1.5 \mathrm{~m}$ height. The plant posses aerial stems (ferns ) and much branched feathery foliage. The leaves are triangular scales like, 3-7 $\mathrm{mm}$ in length. The cladodes (modified stems ) arise in the axis of scale leaves . Cladodes are found in fascicles (3-6) on each node, they perform photosynthesis. Male plants produce thicker spears than female plants. The flowers are bell- shaped, greenish-white to yellowish, 4.5-6.5 mm long, with 6- tepals, single or in clusters of 23 . The female flower contains a well -developed pistil and vestigial stamens. The male flower has six developed stamens. Seeds are monocots, endospermic, flattened, ellipsoid to rounded with a deep black outer testa, contain small and straight embryos . Germination is hypogeal, primary root does not persist long, its function is replaced by numerous adventitious roots arising on the rhizome. The crowns consist of rhizomes ,fleshy stems, with roots attached on the under surface, as well as buds.

SEM exhibited that the seed epidermal cells show globose with isodiametric, slightly elongated oval epidermal cells . Cladode epidermal cells show low density of stomata. The stomata appeared obviously anomocytic type .Slightly elongated reticulate papillae was distinguished, and the surface is densely covered with waxy crystals. The scale-like leaf (adaxial surface ) has a wavy irregular epidermis with high density of anomocytic stomata embedded inside grooves .It has wavy crystalline and heavy papillae reticulate trichomes. Abaxial surface of scale - like leaf shows a regular epidermal cells with large numbers of open paracytic stomata. There are low density of hairy trichomes .
\end{abstract}

Key wards: Asparagus morphology, SEM investigations, trichomes.

\section{INTRODUCTION}

Asparagus (Asparagus officinalis L.) is one of the promising nontraditional horticultural crops in Egypt. It is a large genus with over 160 different species of herbaceous perennial crops of high economic value, with a chromosome number of $2 n=20$. It originated mainly in Asia and Africa (Prophen et al., 2008). The most common economically important species of Asparagus is Asparagus officinalis L., which is a highly prized dioeciously vegetable crop (Stajner et al., 2002). Male plants show higher yields and vigor than those of female individuals. Tender and unexpanded shoots, commonly called spears, are the edible organs of garden asparagus and a plant can produce spears for up to 15 years (Rubatzky and Yamaguchi, 1997). Asparagus is one of the most nutritionally well balanced vegetables in existence, high in folic acid, thiamin, vitamin B6 and a good source of potassium. It represents sources of rutin, a drug which strengthens capillary wall, also an excellent source of folacin, which helps in the duplication of cells for growth and repair of the body and in blood cell reproduction in the bone marrow. It contains glutathione, has no fat, no cholestrol and low in sodium (Hassan, 2001).

Roemer and Schultes (1829) classified Asparagus as a genus within the family Liliaceae. The genus followed this family by all subsequent taxonomists until Dahlgren and Clifford (1982). After that Huber (1969, 1977), revived the idea of three separate genera. At the same time they transferred Asparagus from Liliaceae to Asparagaceae, in which it included the three genera: Asparagus, Asparagopsis and Myrsiphyllum. Although Aspargus officinalis L. is chiefly known as a vegetable herb as mentioned above, little information about the botanical characteristics is available. 
Therefore, this study aimed to shed some light on more information about some botanical aspects of is plant organs.

\section{MATERIALS AND METHODS}

Seeds of Asparagus officinalis L.( (cv.Mary Washington 500W) were procured from the Agriculture Research Center (Institute of Vegetables), Dokki, Giza, Egypt.

The field experiment was carried out in the Experimental and Research station of the Faculty of Agriculture, Cairo Univ., Giza, Egypt during the three successive growing seasons 2012, 2013,2014 to provide the experimental plant material. Seeds were sown on the February $2^{\text {nd }}, 2012$. The trial included 3 replicates. All field practices for Asparagus officinalis L. were carried out as recommended. Seedlings were taken out for morphological investigations at the end of the seedling stage (28 days). The crown system (subterranean rhizome and adventitious roots) was investigated at the end of the second season. The shoot system was described morphologically and the spear yield of the shoot was followed up to determine the nature and the habit of asparagus growth.

Seeds,scale-like leaf and cladodes of Asparagus officinalis L. plant were investigated by Scanning Electron Microscope (SEM). The specimens were mounted after dehydration on the copper specimen holder stub with a doublesides adhesive disc and coated with a thin layer of gold palladium using Edwards Sputter Coater units 150A, (England) (Voigt and Gorb 2009) . The specimens were examined in different positions using different magnification by JXA840A model electron probe analyzer (JEOL, Japan). SEM was carried out at National Research Center (NRC), Dokki, Giza, Egypt.

\section{RESULTS AND DISCUSSION \\ 3.1.The seed and seedling}

Seeds are rounded, flattened side and a little wrinkled seed coat, which have a black outer epidermis and contains albuminous endosperm with small straight embryo attached to one cotyledon. It forms two thirds to almost as long as the endosperm. Seed possess ventrally angular hilum in conjunction with a convex dorsal side. The diameter of asparagus seed was about 2.5$3 \mathrm{~mm}$ (Fig.1).

The seedling ( 3 weeks old)were characterized by the presence of short hypocotyls. The seedling collar was not conspicuous. Hypogeal is the germination type. The plumule was curved then became straight as it appeared above the soil surface. It carried the main stem with simple, membraneous small cladodes (modified stems), which constituting the part of the plant ordinarily seen (Fig .1). The primary root does not persist long; its function is replaced by numerous of adventitious roots arised mainly on the rhizome. These results are in agreement with those of Shukla and Misra (1979) and Pandy (2004).

\subsection{The root system (the crown )}

The root system is adventitious and the type is fasciculated (Fig. 2). The crown consists of rhizomes, fleshy stems, with roots attached to their basal portion. Furthermore the crown contains the buds of nascent spears sticking up (marketable yield ). At the age of 2 years - old, the diameter of the crown was about $15-20 \mathrm{~cm}$. For best results, crowns used for planting must be 2 years -old. The young aerial stems or spears (about 20-25 cm long) arising from rhizomes are consumed as a vegetable (Fig.3.a \& b). These findings are in harmony with those of Clarence (1954) and Tanming and Chantaranathai (2011) .

\subsection{The shoot system}

Asparagus is a herbaceous, perennial ,dioeciously vegetable crop, growing to $1-1.5 \mathrm{~m}$ tall, with stout stems (ferns) with much branched feathery foliage. The leaves are triangular scale- like $3-7 \mathrm{~mm}$ in length. The cladodes (modified stems ) arise in the axis of scale leaves. The aerial erect shoot carry cladodes (cladophylls ).The cladodes are found in fascicles (3-6) on each node these perform photosynthesis . They are $8-30 \mathrm{~mm}$ long and about 1-2mm broad (Fig.3c). Male plants produce thicker spears than female, which put a considerable amount of energy into producing seeds. Male and female individuals occur in approximately $1: 1$ ratio .

The flowers are bell shaped, greenish -white to yellowish , $4.5-6.5 \mathrm{~mm}$ long . Tepals are partially fused together at the base. Flowers are produced single or in clusters of 2-3 in the junctions of the branchlets (Fig. 4). The female flower contains a well developed pistil and vestigial stamens, but the male flower has six developed stamens. The fruit is small red berry at maturity,6-8 $\mathrm{mm}$ in diameter, which is poisonous to human (Fig.4). These findings are in agreement with those of Tanming and 


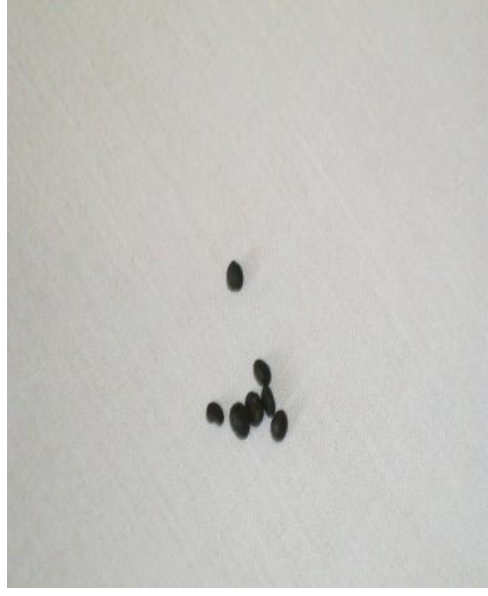

a

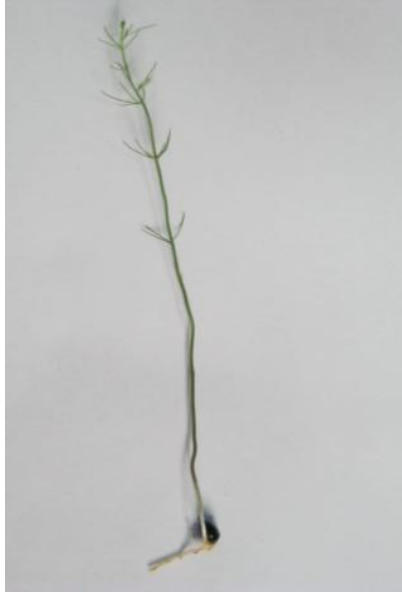

b

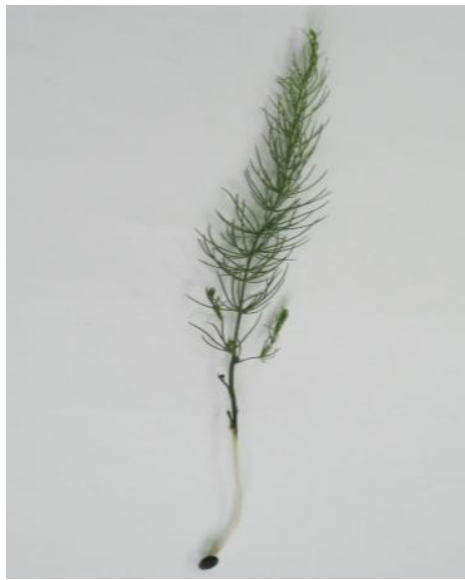

C

Fig. (1) : (a)The whole seeds, b)Completely developed seedling (3-weeks old ) and c) 4 weeks old, of Asparagus officinalis L.

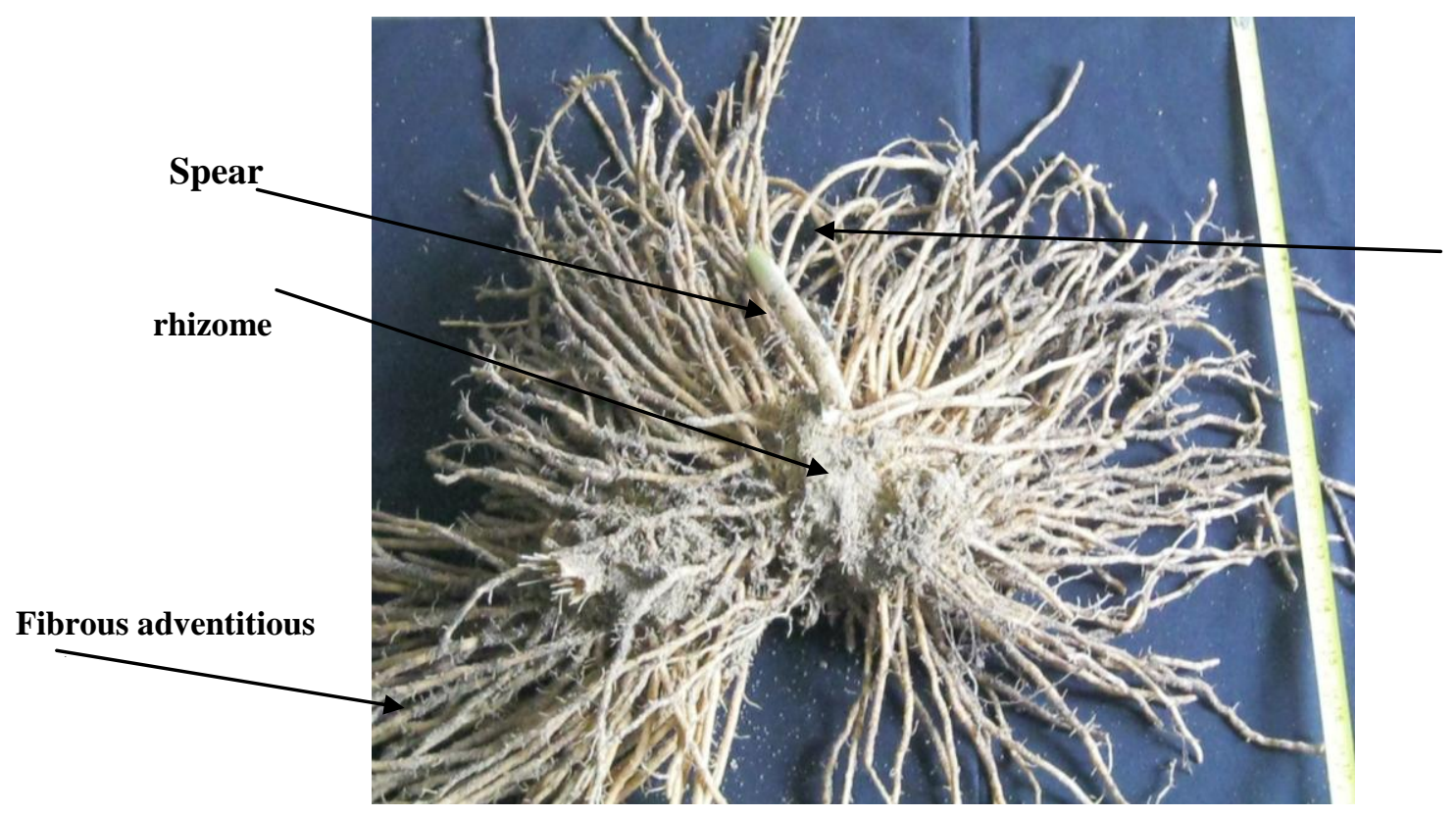

Thick adventitious roots

Fig.(2): The underground crown of Asparagus officinalis L . 


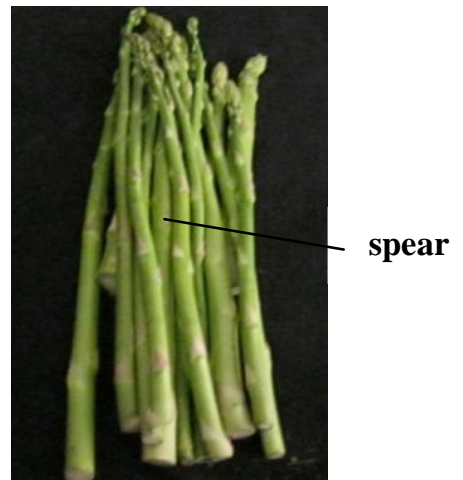

a

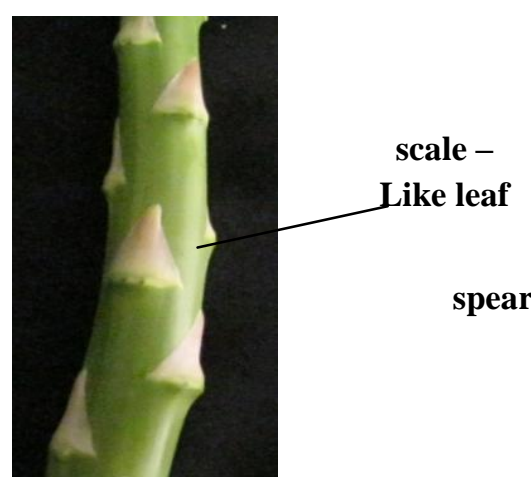

b

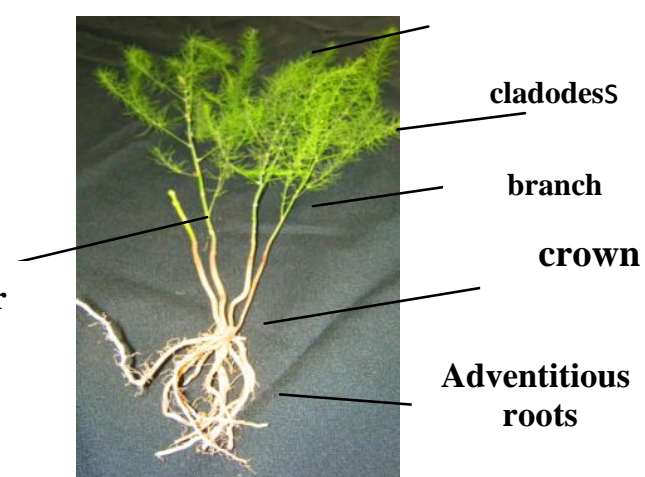

Fig. (3): Asparagus officinalis $\mathrm{L}$. at the vegetative growth. (a)Marketable yield (spears)at age of 20 weeks (b) Magnified portion of (a) shows the like-scale leaves, and (c) The vegetative growth at 20 weeks -old.

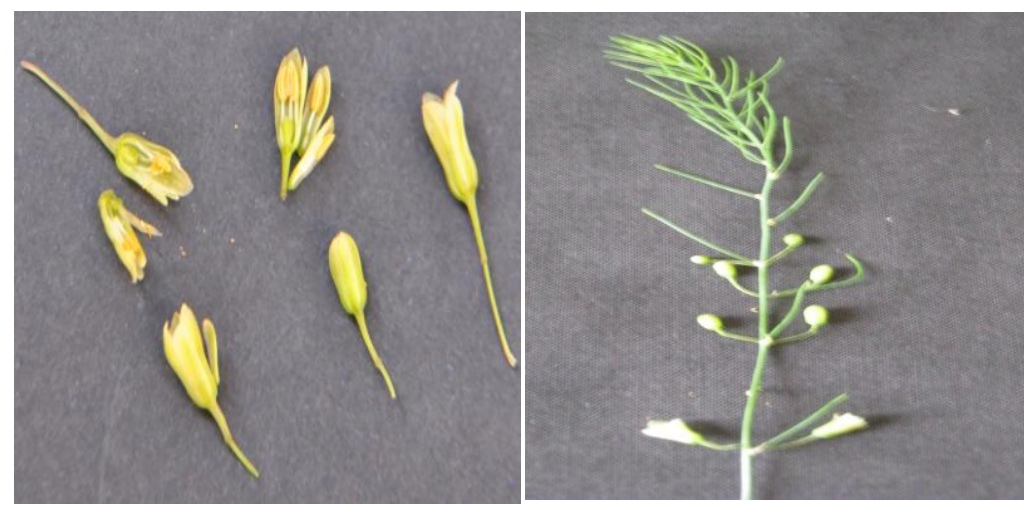

(a)

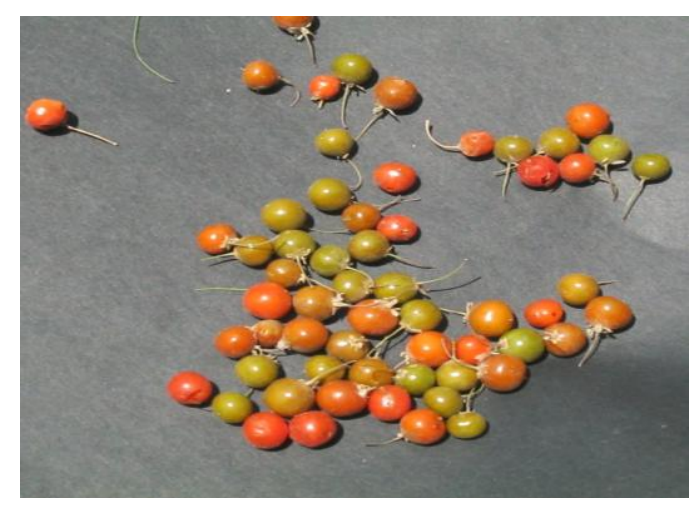

(b)
Fig.(4): Asparagus officinalis L .
(a) Flowers
(b) Fruits 


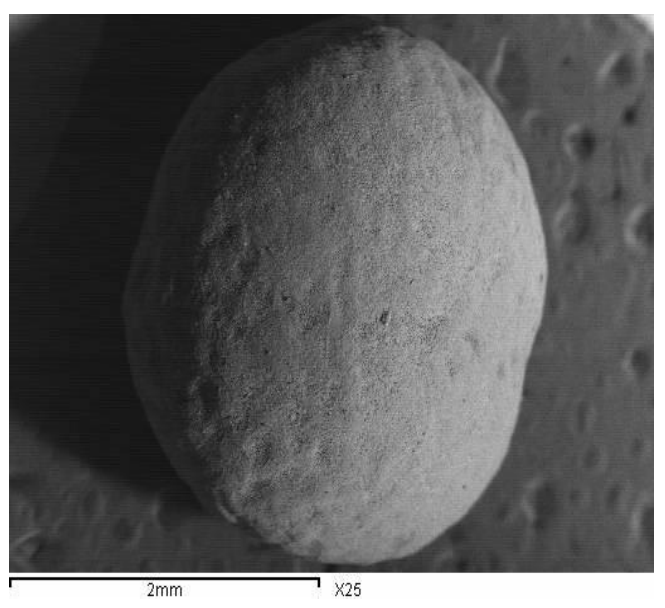

a $(\mathrm{x} 25)$

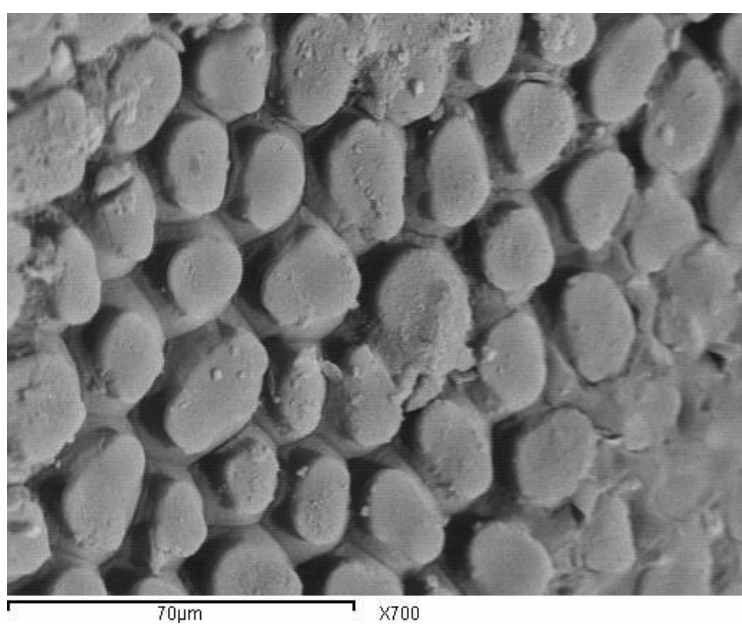

b $(x 700)$

Fig.(5) : Scanning Electron Microscope of seed of Asparagus officinalis L.

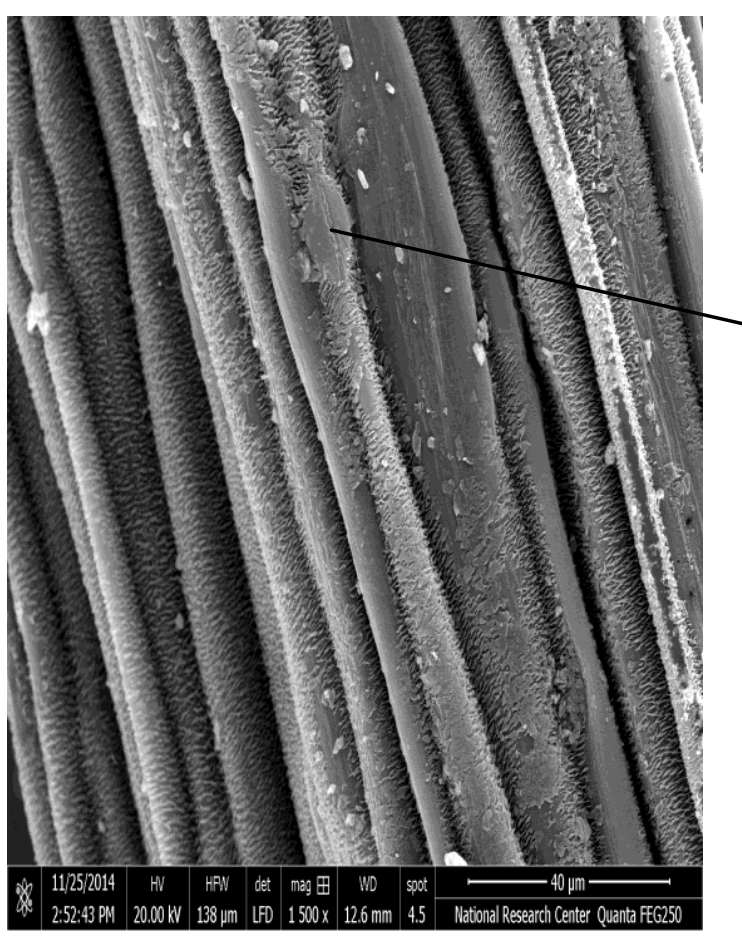

a

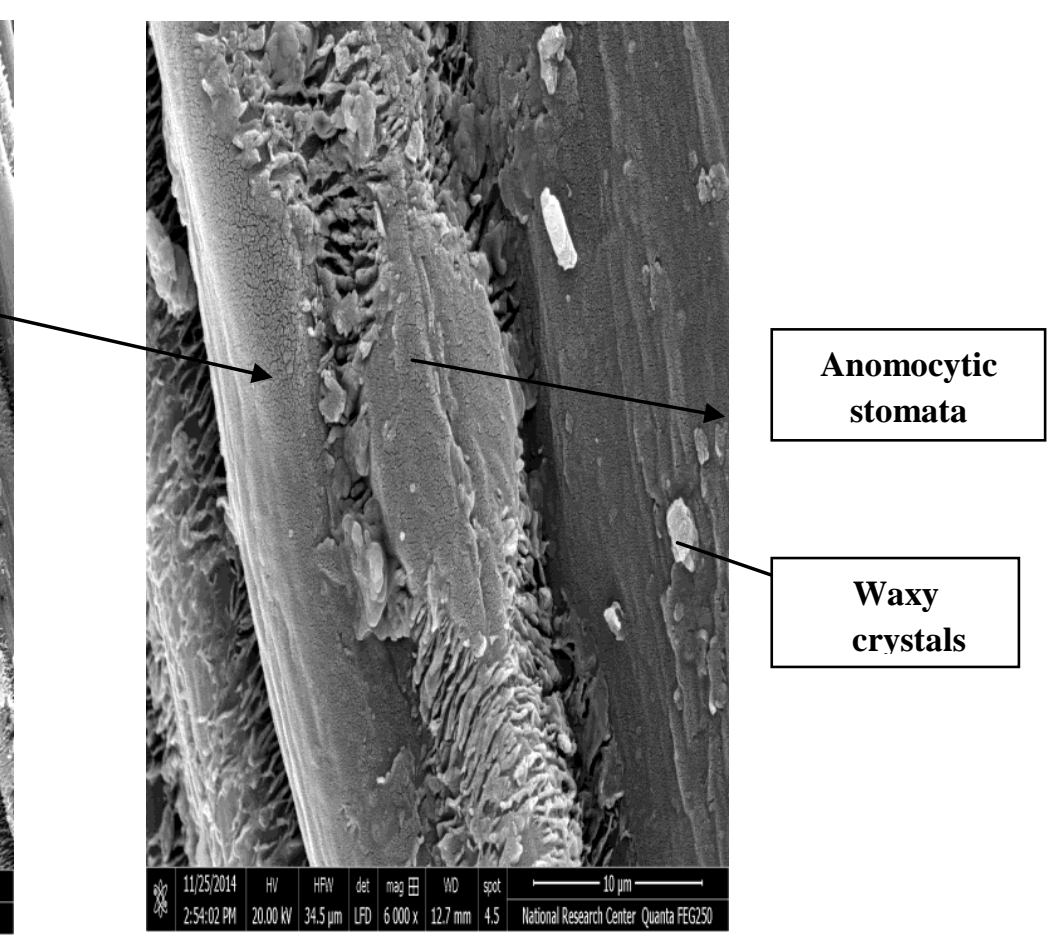

b

Fig.(6): Scanning Eelectron Microscope of cladode epidermal cells of Asparagus officinalis $\mathbf{L}$. (a) scale bar at $40 \mu \mathrm{m}$, (b) scale bar at $10 \mu \mathrm{m}$. 


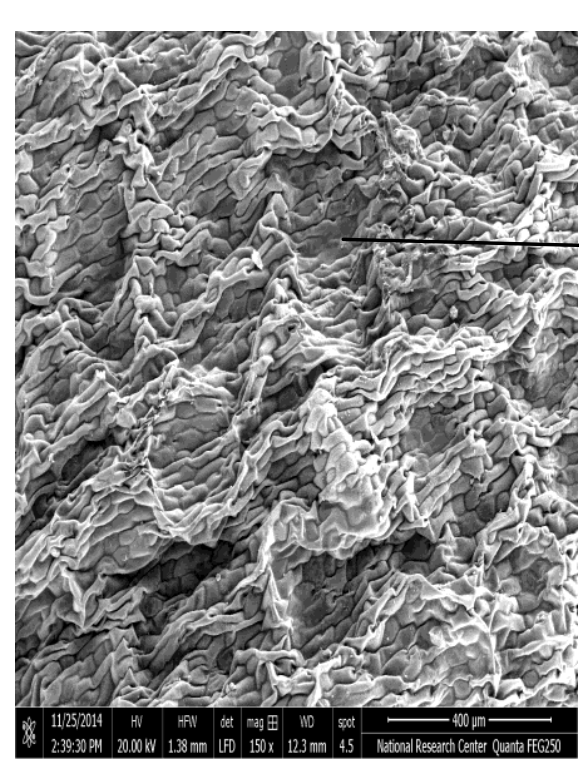

(a) $400 \mu \mathrm{m}$

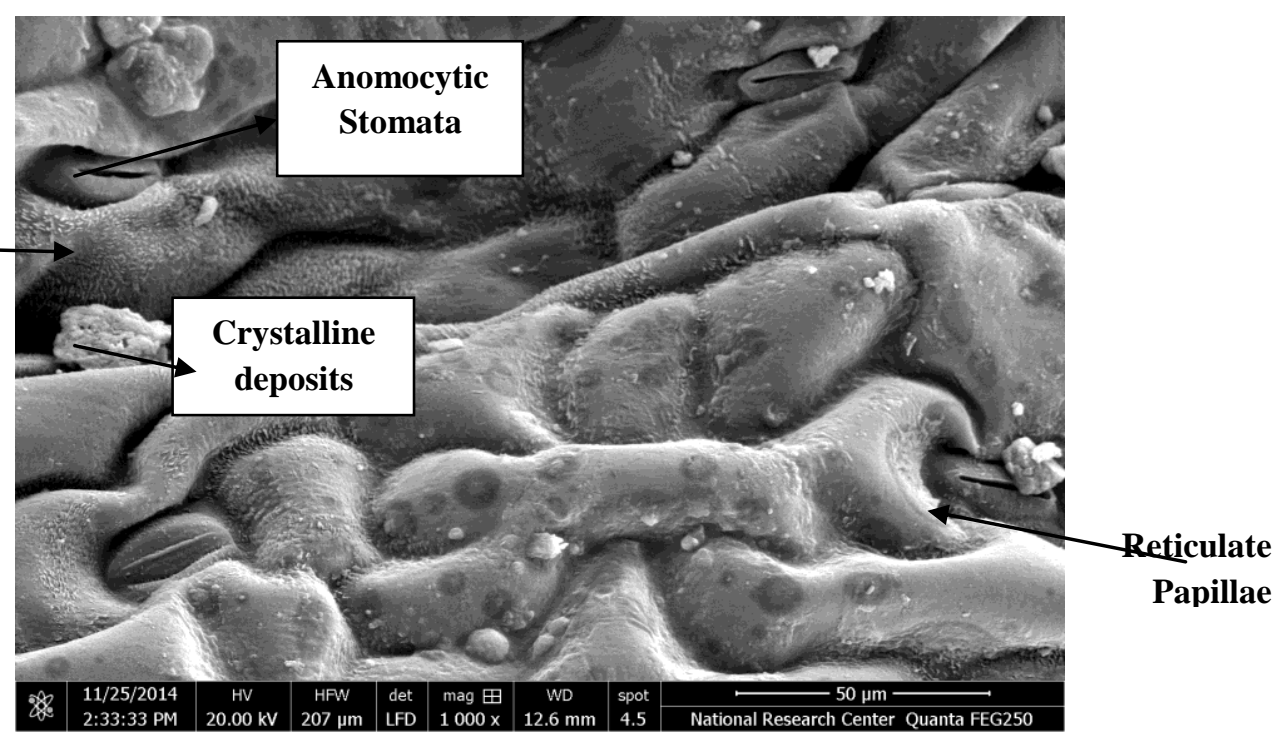

(b) $50 \mu \mathrm{m}$

\section{adaxial surface}

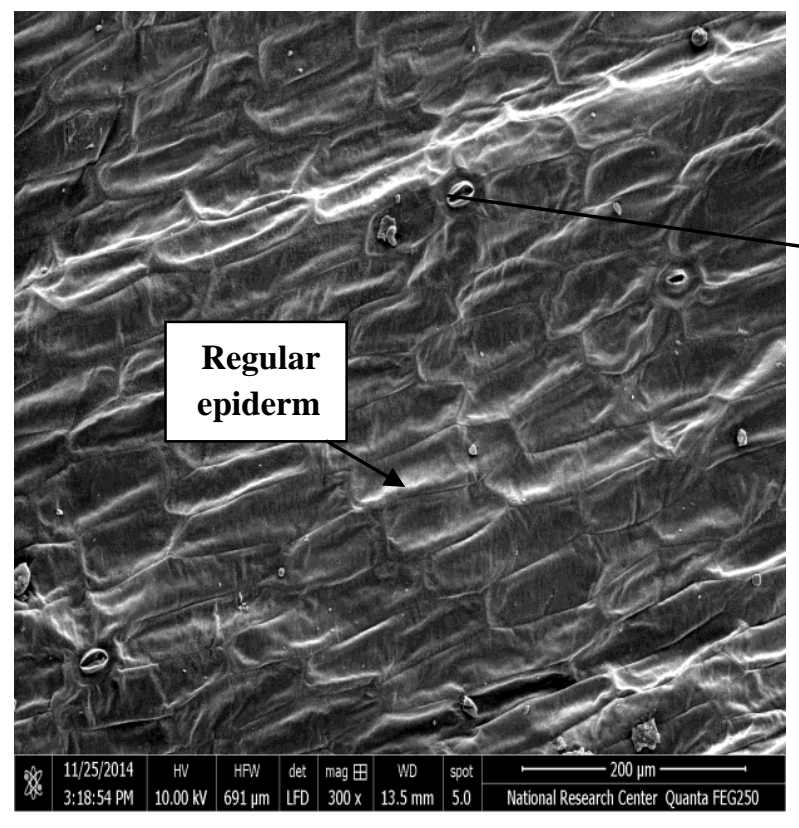

(c) $200 \mu \mathrm{m}$

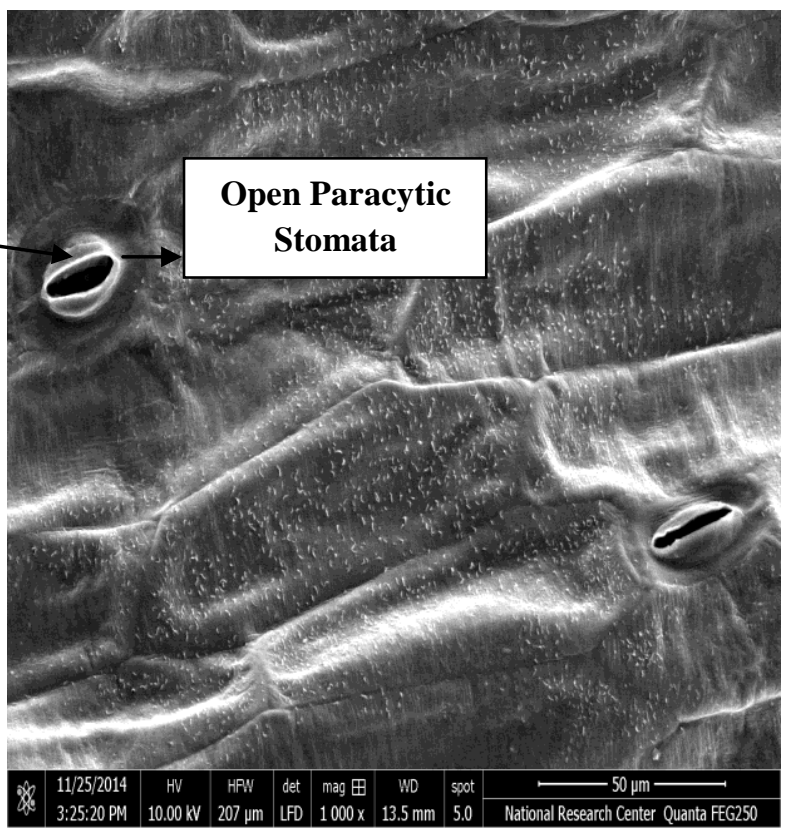

(d) $50 \mu \mathrm{m}$

\section{abaxial surface}

Fig.(7): Scanning Electron Microscope of the scale- like leaf of the Asparagus officinalis L.; $(a \& b)$ adaxial surface and $(c \& d)$ abaxial surface . 
Chantaranathai (2011), Hyde et al., (2012) Dale (2013) and Watson and Dalwitz (1992).in agreement with those of Tanming and Chantaranathai (2011) Hyde et al., (2012) Dale (2013) and Watson and Dallwtz (1992).

\subsection{Scanning Electron Microscope investigation (SEM}

Seed epidermal cells of Asparagus officinalis L. are illustrated in Fig. (5a\&b). Seeds appeared globose, with isodiametric slightly elongated oval epidermal cells.

Cladode epidermal cells show low density of anomocytic stomata. (Fig. 6). Slightly elongated reticulate papillae were also observed. The surface of cladode is covered densely with waxy crystals.

Crystalline wax found in heavy platelets form arranged in rows transversely parallel to longitudinal axis . The asparagus cladode surface is expected to posses distinct hydrophobic properties combined with crystalline waxy deposits, these provide surface with hydrophobic character. The aforementioned results are in agreement with those of Malcomber and De Demisses (1992) and Barthlott and Neinhuis ( 1997) .

The epidermis of adaxial surface of scale like leaf is wavy irregular with high density of anomocytic stomata embedded inside grooves Fig. (7). It is characterized by the presence of waxy crystalline deposits and the presence of heavy reticulate papillae trichomes. The abaxial surface of scale-like leaf shows the presence of regular epidermal cells with large numbers of open paracytic stomata .As parallel subsidiary cells were present, low density of hairy trichomes were recognized. These results are in harmony with those of Gorb (2001) and Voigt and Gorb (2009).

\section{REFERENCES}

Barthlott W. and Neinhus C .(1997). The purity of the sacred lotus, or escape from contamination in biological surface.planta1-8.

Clarence J.H. (1945). The wild flower book description text ,illustrating Edith Farrington Johnston. The Macmillan Company. NEW York USA.: 21 P.

Dahlgren R.M.T. and Clifford H.T.(1982). The monocotyledons: A comparative study. Academic press , London UK : PP 318-337.
Dale W.M. (2013). depson eflora, http: // uncjepps . bekeley. edu/I\} M.html ,accessed on Jun $15^{\text {th }}$. 2014.

Gorb S.(2001). The attachment devices of insect cuticle, Dordrecht. The Nether lands: Kluwer Academic publishers, 305P.

Hassan N.A.( 2001). Growth, yield ,spear quality and some genetical and Character of six Asparagus officinalis L. cultivars . department of vegetable crops faculty Of Agriculture . Cairo university. PP1-4.

Huber H. (1969). Die samen merkmale and verwandtschafts Verhaltnissc die LILiiflorae. Mitt.Bot. Staatssammi. Muchen 8:219-538.

Huber H. (1977). The treatment of monocotyledon in an evolutionary system of Classification Plant Syst. Evol., suppi.1: 285-298.

Hyde M.A., Wursten B.T. and Balling P. (2012). The Asparagaceae flora of Zimbabwe website Access.

Malcomber S.T. and Demisses S. (1992).The status of protasparagus and Myrsiphyllum in the Asparagaceae. The herbarium .Royal Botanic Garden, Kew, Richmond, U. K.,

Pandey B.P.(2004). Economic Botany, S.chand and Company ltd. Ram Nagar, Newdelhl, India , PP358-359.

Prophen G., Luez F. and Carena M.G .(2008). The hand book of plant breeding . springer publishing In: 364P

Roemer J.J. and Schultes J.A.(1829).C.Linne , Systema Vegetabilium 7: 317-337, J.G .Cotta , ed. Stuttgart, Germany.

Rubatzky V.E. and Yamaguchi M.(1997). The world vegeta-edn. Chapman $\alpha$ Hall. New York: 370P.

Shukta P and Misra S .(1979). The introduction to taxonomy of Angiosperm . Vikas Publishing House PVT Ltd., New Delhi, ,India , PP488-494.

Stajner N., Bohanec B. and Javornik B.(2002).The Genetic Variablity of economically important Asparagus species as revealed by genome size analysis and rDNA its polymorphism. Plant Science, 162.(6) 931 -937.

Tanming W. and Chantaranothai P. (2012). The account of Asparagaceae in Thailand. .Applied Taxonomic Research Center, Tropical Nature History, 12 (1):PP 43-53.

Voigt D. and Gorb S. (2009). The egg attachment of the asparagus beetle 
Proceedings of the Royal Society . B(2010) 277: PP 895-903.

Watson L. and Dalwitz M. J. (1992). The families of flowering plants : descriptions
Illustration, identification and information retrieval version : 2013.http :// delta-intkey .com.

\section{دراسات نباتية علي الاسبرجس( الهليون).Asparagus officinalis L الفصيلة الاسبرجسية

$$
\text { رمضان قرني حرب- اسامه سليمان القبيصي - سالي فرج دسوقي }
$$$$
\text { قسم النبات الزر اعي ـكلبة الزراعة- جامعة القاهرة-جيزة- مصر }
$$ \\ ملخص الفاه}

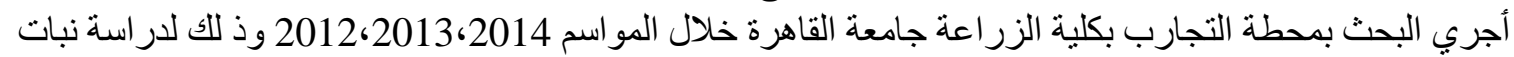

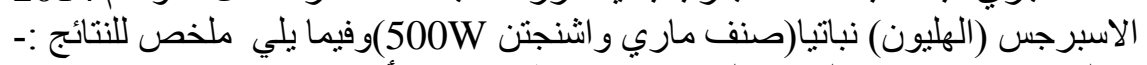

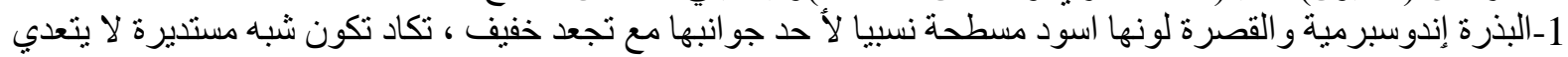

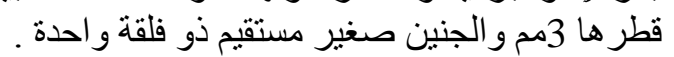

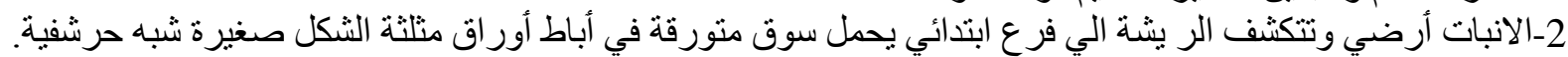

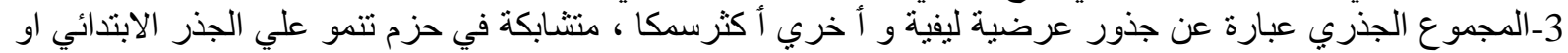

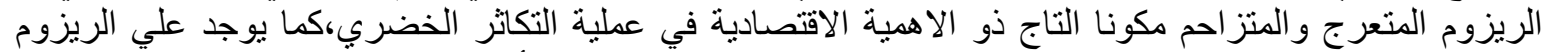

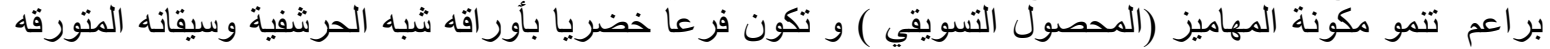

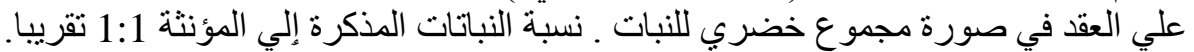

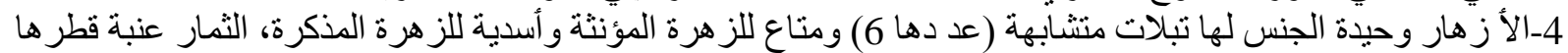

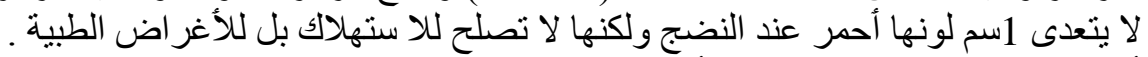

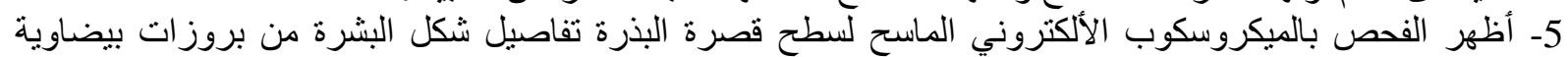

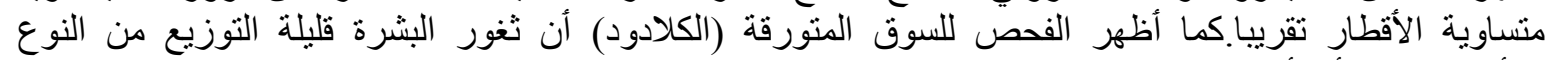

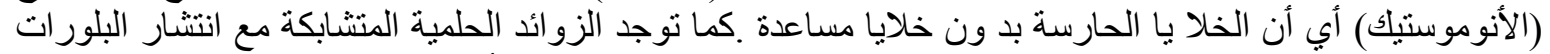

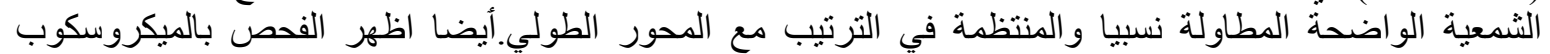

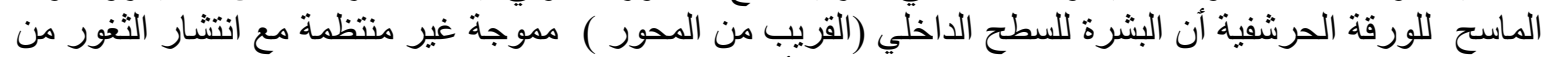
النوع الاول( بد ون خلايا مساعدة)ولكنها مطمورة داخل أخاديد مع وجود البلور ات الثية الثمعية والزوروائد الحلمية الثبكية

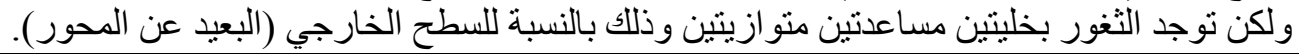

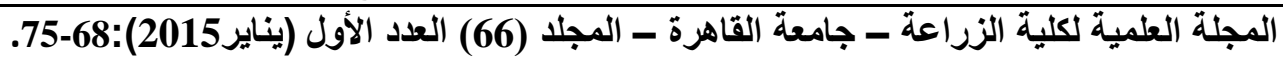

